\title{
Arsenic affects inflammatory cytokine expression in Gallus gallus brain tissues
}

\author{
Xiao Sun ${ }^{\dagger}$, Ying He ${ }^{\dagger}$, Ying Guo, Siwen Li, Hongjing Zhao, Yu Wang, Jingyu Zhang* and Mingwei Xing* (D)
}

\begin{abstract}
Background: The heavy metal arsenic is widely distributed in nature and posses a serious threat to organism's health. However, little is known about the arsenic-induced inflammatory response in the brain tissues of birds and the relationship and mechanism of the inflammatory response. The purpose of this study was to explore the effects of dietary arsenic on the expression of inflammatory cytokines in the brains of Gallus gallus.

Results: Seventy-two 1-day-old male Hy-line chickens were divided into a control group, a low arsenic trioxide $\left(\mathrm{As}_{2} \mathrm{O}_{3}\right)$-treated $(7.5 \mathrm{mg} / \mathrm{kg})$ group, a middle $\mathrm{As}_{2} \mathrm{O}_{3}$-treated $(15 \mathrm{mg} / \mathrm{kg})$ group, and a high $\mathrm{As}_{2} \mathrm{O}_{3}$-treated $(30 \mathrm{mg} / \mathrm{kg})$ group. Arsenic exposure caused obvious ultrastructural changes. The mRNA levels of the transcription factor nuclear factor- $\mathrm{KB}$ (NF-KB) and of pro-inflammatory cytokines, including inducible NO synthase (iNOS), cyclooxygenase-2 (COX-2), and prostaglandin E synthase (PTGEs), in chicken brain tissues (cerebrum, cerebellum, thalamus, brainstem and myelencephalon) on days 30,60 and 90, respectively, were measured by real-time PCR. The protein expression of iNOS was detected by western blot. The results showed that after being treated with $\mathrm{As}_{2} \mathrm{O}_{3}$, the levels of inflammatory-related factor NF-KB and pro-inflammatory cytokines in chicken brain tissues increased $(P<0.05)$.

Conclusions: Arsenic exposure in the chickens triggered host defence and induced an inflammatory response by regulating the expression of inflammatory-related genes in the cerebrum, cerebellum, thalamus, brainstem and myelencephalon. These data form a foundation for further research on arsenic-induced neurotoxicity in Gallus gallus.
\end{abstract}

Keywords: Arsenic, NF-kB, Inflammatory cytokines, Brain tissues, Chickens

\section{Background}

Arsenic is one of the most toxic substances from the natural environment and is classified as a human carcinogen (Group I) [1]. It is widely distributed in natural sources (earth crust, air, soil), anthropogenic sources (insecticides, feed additives, industrial waste), and in drugs and poisons in both organic and inorganic forms [2]. Arsenic reacts with environmental oxygen, chlorine, and sulfur, generating more toxic, soluble inorganic compounds $\left(\mathrm{AsO}_{4}^{3-}\right.$ and $\left.\mathrm{AsO}_{3}^{3-}\right)$, and posses a serious threat to organism health [3]. Dermal exposure to toxic trivalent or pentavalent arsenic compounds can produce skin cancer, melanosis, and dorsum [4]. Inhalation of arseniccontaminated air can affect the respiratory system and can cause laryngitis, rhinitis, and pulmonary diseases

\footnotetext{
* Correspondence: zhangjingyu@foxmail.com; xingmingwei@nefu.edu.cn ${ }^{\dagger}$ Equal contributors

College of Wildlife Resources, Northeast Forestry University, Harbin, Heilongjiang Province 150040, China
}

$[5,6]$. Arsenic-contaminated water can be absorbed by the digestive system and leads to gastritis, abdominal pain, and anorexia. Moreover, selenium deficiency can cause muscular dystrophy in various species, arsenic can also damage the liver, kidneys, heart, and reproductive and nervous systems [7-12]. Arsenic can traverse the blood brain barrier and accumulate in different regions of the brain, making it a target organ of arsenic toxicity and suggesting a role for it in neurological diseases [13, 14]. Because of their toxic effects, pollution of the environment with arsenic and arsenic compound attracts public attention [15].

Previous studies showed that the development of toxicity or alteration in cytokines level induced by molybdenum, cadmium, selenium and lead, which was assessed by evaluating mRNA expression and western blot [16-18]. Developing brain tissue is vulnerable to toxic arsenic [19], and arsenic causes histopathological changes to developing brain tissue (unpublished data). Several reports 
have indicated that acute or chronic exposure to inorganic arsenic causes neural injury [20]. However, little is known regarding whether arsenic-induced neural injury will result in an inflammatory response in the brain tissues of birds. One of the hallmarks of the inflammatory response is the production of pro-inflammatory mediators, which are needed to repair injured tissues [21, 22]. Nuclear transcription factor- $\mathrm{kB}(\mathrm{NF}-\mathrm{\kappa} \mathrm{B})$ is attached to regulatory proteins named inhibitors of $\kappa \mathrm{B}(\mathrm{I} \kappa \mathrm{B})$ and kept inactive in the cytosol [23]. IкB $\alpha$ and $I_{\kappa} B \beta$ are the main proteins involved in NF- $\mathrm{B}$ activation and sustained activation, respectively. $\mathrm{NF}-\kappa \mathrm{B}$ is activated under inflammation stimulation and then moves to the nucleus, recognizes the promoter region and regulates the transcription of the pro-inflammatory genes inducible NO synthase (iNOS) and cyclooxygenase-2 (COX-2) [24-26]. iNOS is a member of the NOS family and is widely distributed in a diverse number of nerve cells, whereas COX-2 is mainly found in specific neurons $[27,28]$. Neither is generally expressed in resting nerve cells, and they are only expressed to take part in inflammatory responses under diverse pathological conditions, such as Alzheimer's disease, ischaemia, and neurodegenerative disorders [29-31]. iNOS and COX-2 have vital roles in the pathophysiology of inflammation because they produce $\mathrm{NO}$ and prostaglandins (PGE), respectively [32-34]. Low concentrations of NO are sufficient to maintain physiological functions; however, elevated NO exerts genotoxic harm on the host [32]. Research on the inflammatory mediators NF- $\mathrm{kB}$, iNOS, COX-2, and prostaglandin $\mathrm{E}$ synthase (PTGEs) in chickens treated with arsenic trioxide $\left(\mathrm{As}_{2} \mathrm{O}_{3}\right)$ may contribute to the understanding of the possible inflammatory mechanisms of heavy metal arsenic in the nervous system of birds.

We explored the effects of arsenic on the mRNA and protein levels of the main inflammatory-related mediators in the brain tissues of Hy-line chickens to answer the question of whether arsenic induced an inflammatory response in chicken brain tissues, specifically the cerebrum, cerebellum, thalamus, brainstem and myelencephalon, by affecting the expression of inflammatory cytokines.

\section{Methods \\ Reagents}

RNAiso Plus and PrimeScript ${ }^{\mathrm{Tm}} \mathrm{RT}$ reagent Kit were purchased from TaKaRa (Dalian, Liaoning, China). FastStart Universal SYBR Green Master was purchased from Roche (Indianapolis, IN, USA). SDS Lysis Buffer, Enhanced BCA Protein Assay Kit and glyceraldehyde3-phosphate dehydrogenase (GAPDH) antibody were purchased from Beyotime (Shanghai, China). A horseradish peroxidase (HRP)-labelled goat anti-rabbit IgG was purchased from Beijing Biosynthesis Biotechnology Co., LTD
(Beijing, China). The iNOS antibody was kindly provided by Professor Xu (Northeast Agricultural University, China).

\section{Animals and experimental design}

Procedures used in the present study were authorized by the Institutional Animal Care and Use Committee of Northeast Forestry University (Harbin, China) (UT-31; 20 June 2014). The Hy-line chicken models were created according to our previous research [35]. In short, 72 1-day-old healthy Hy-line chickens, purchased from Weiwei Co. Ltd., Harbin, China., were randomly divided into four groups (18 cocks per group): a control group, a low $(7.5 \mathrm{mg} / \mathrm{kg}) \mathrm{As}_{2} \mathrm{O}_{3}$-treated group (L group), a middle (15 mg/kg) $\mathrm{As}_{2} \mathrm{O}_{3}$-treated group (M group), and a high (30 mg/kg) $\mathrm{As}_{2} \mathrm{O}_{3}$-treated group ( $\mathrm{H}$ group), which arsenic doses of dietary were daily administration by adding $\mathrm{As}_{2} \mathrm{O}_{3}$ into the food to make supplements uniformed according to the chicken median lethal doses $\left(\mathrm{LD}_{50}\right)$ of 0 , $1 / 80,1 / 40,1 / 20$, respectively. The composition of the diet is: Maize, grains $421 \mathrm{~g} / \mathrm{kg}$; Wheat, grains $120 \mathrm{~g} / \mathrm{kg}$; Full fat soy 180 g/kg; Pea 100 g/kg; Wheat bran 80 g/kg; Limestone $80 \mathrm{~g} / \mathrm{kg}$; Dicalcium phosphate $15 \mathrm{~g} / \mathrm{kg}$ and Sodium chloride $4 \mathrm{~g} / \mathrm{kg}$. This diet met the minimum requirements for energy and nutrients for chicken and without influencing results according to Nisianakis et al. [36]. Food and water were provided ad libitum. During the experiments, all chickens were injected with sodium pentobarbital to abate stress. Six brain tissue samples (cerebrum, cerebellum thalamus, brainstem and myelencephalon) were taken on day 30, 60 and 90, excised and then rinsed with icecold sterilized deionized water, and promptly frozen in liquid nitrogen until required.

\section{Ultrastructural observations}

For electron microscopy, brain tissue specimens were fixed with $2.5 \%$ glutaraldehyde in $0.1 \mathrm{M}$ sodium phosphate buffer ( $\mathrm{pH} 7.2$ ) for $3 \mathrm{~h}$ at $4{ }^{\circ} \mathrm{C}$, washed in the same buffer for $1 \mathrm{~h}$ at $4{ }^{\circ} \mathrm{C}$ and post-fixed with $1 \%$ osmium tetroxide in sodium phosphate buffer for $1 \mathrm{~h}$ at $4{ }^{\circ} \mathrm{C}$. The tissues were then dehydrated in a graded series of ethanol starting at $50 \%$ ethanol for $10 \mathrm{~min}$ at a time and then were immersed twice in propylene oxide. The tissue specimens were embedded in araldite. Ultrathin sections were stained with Mg-uranyl acetate and lead citrate for evaluation using a transmission electron microscope.

\section{Primers}

Primers used in the present study to detect inflammatory cytokine expression in chickens treated with $\mathrm{As}_{2} \mathrm{O}_{3}$ are shown in Additional file 1 [26]. GAPDH was considered a housekeeping gene and was used in this study as an internal reference. 


\section{Total RNA isolation and reverse transcription}

Total RNA from chicken brain tissues was isolated using RNAiso Plus (Takara, China). The concentration and purity were analysed by measuring the absorbance at 260 and $280 \mathrm{~nm}$ on a spectrophotometer (Ultrospec 1100 pro, Amersham Biosciences, China). The first-strand cDNA was synthesized using the PrimeScriptTMRT reagent Kit (TaKaRa, China) according to the manufacturer's instructions. The single chain cDNA was diluted tenfold with sterile $\mathrm{ddH}_{2} \mathrm{O}$ and stored at $-80{ }^{\circ} \mathrm{C}$ before use.

\section{Quantitative real-time PCR}

Quantitative real-time PCR was performed on a BIOER LineGene 9600 Real-Time PCR System (Hangzhou, China). Reactions contained $5 \mu \mathrm{L}$ of the SYBR Green Master Mix (Roche, USA), $1 \mu \mathrm{L}$ of diluted cDNA, $1 \mu \mathrm{L}$ of each primer $(10 \mu \mathrm{M})$ and $2 \mu \mathrm{L}$ of $\mathrm{ddH}_{2} \mathrm{O}$ water. The reaction conditions were set at $95^{\circ} \mathrm{C}$ for $10 \mathrm{~min}$, followed by 40 cycles of $95{ }^{\circ} \mathrm{C}$ for $15 \mathrm{~s}$ and $60^{\circ} \mathrm{C}$ for $1 \mathrm{~min}$. A single peak could be seen in the melting curve. The relative abundance of mRNA was calculated using the $2^{-\Delta \Delta C t}$ method and normalized to the mean expression of GAPDH [37].

\section{Western blot analysis}

Total protein from chicken brain tissues was extracted using SDS Lysis Buffer (Beyotime, China). The concentrations of the protein extracts were measured and calculated using the Enhanced BCA Protein Assay Kit (Beyotime, China). Equal amounts of protein from each extract were subjected to $12 \%$ SDS-PAGE gel electrophoresis. Separated proteins were transferred to nitrocellulose (NC) membranes in Tris-glycine buffer for $1 \mathrm{~h}$ at $100 \mathrm{~mA}$. The NC membranes were blocked with 5\% skim milk at $37{ }^{\circ} \mathrm{C}$ and $50 \mathrm{rpm}$ for $4 \mathrm{~h}$ and incubated overnight with the diluted iNOS primary antibody (1:1000, provided by Dr. Xu) and GAPDH antibody (1:1000, Beyotime, China) followed by a $1 \mathrm{~h}$ incubation with a horse-radish peroxidase (HRP)-conjugated goat anti-rabbit IgG (1:5000, Bioss, Beijing) at $37{ }^{\circ} \mathrm{C}$ and $50 \mathrm{rpm}$. The signals were detected by X-ray film (Kodak, USA), and the corresponding protein expression levels were calculated according to greyscale values of the iNOS and GADPH bands.

\section{Statistical analyses}

GraphPad Prism 5 statistical software was used to analyse the data. When a significant value $(P<0.05)$ was obtained by one-way ANOVA, further analysis was carried out. All data showed a normal distribution and passed equal variance testing. Differences between means were assessed using Tukey's honest significant difference test for post hoc multiple comparisons. Data are expressed as the mean \pm SD of 6 observations.

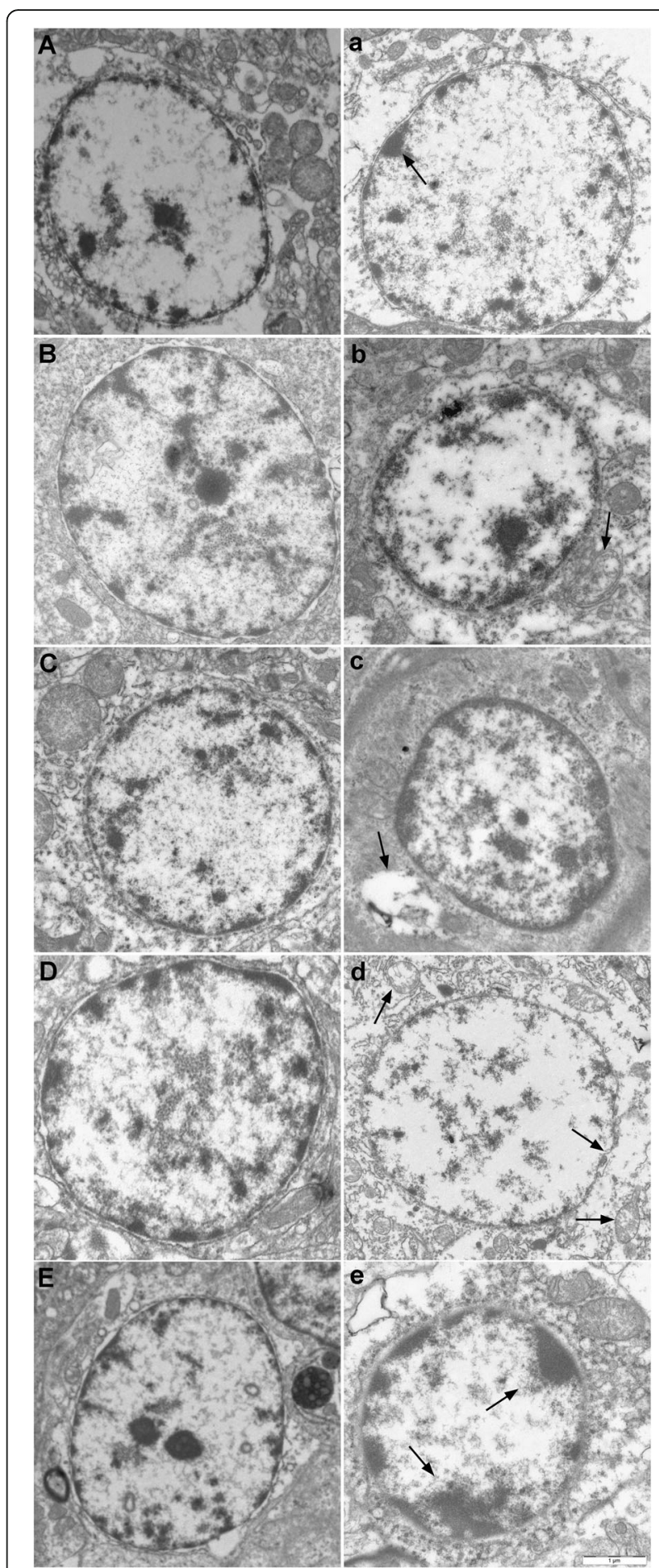

Fig. 1 Ultrastructural observations in the brain tissues of chickens. Panels $A, B, C, D$ and $E$ were the histology of the cerebrum, cerebellum, thalamus, brainstem and myelencephalon tissue in the control group, respectively. Panels $\mathbf{a}, \mathbf{b}, \mathbf{c}, \mathbf{d}$ and e represented the histology of the cerebrum, cerebellum, thalamus, brainstem, and myelencephalon tissue in the $\mathrm{As}_{2} \mathrm{O}_{3}$ treated groups at $90 \mathrm{~d}$ ( $\mathrm{H}$ groups) 


\section{Results}

All treatment groups showed no mortality during our experiments when compared with the controls. We observed no significantly differences between the feed intake, water intake and the body weight of $\mathrm{As}_{2} \mathrm{O}_{3}$-treated group and the control group.

\section{Ultrastructural changes}

The brain tissues from the control groups showed a normal ultrastructure with cells that had smooth rounded nuclei, intact nuclear membranes, normally distributed chromatin, and integrated mitochondria with normal cristae (Fig. 1A-E). Arsenic treatment caused extensive injury of the brain tissues. The mitochondria in brain tissues of the arsenic groups were swollen and vacuolated with degeneration or loss of cristae. The cells showed typical chromatin condensation and margination, fusion of nuclear membrane, and shrinkage of their nuclei. In addition, the nuclei and organelles of some cells were unclear (Fig. 1a-e).
Effects of $\mathrm{As}_{2} \mathrm{O}_{3}$ on NF-KB mRNA levels in the brain tissues of chickens

The NF- $\kappa \mathrm{B}$ mRNA levels in the brain tissues treated with $\mathrm{As}_{2} \mathrm{O}_{3}$ are shown in Fig. 2. The NF-kB levels increased in a dose-dependent manner in the cerebrum, cerebellum, thalamus, brainstem and myelencephalon tissues compared with the control group $(P<0.05)$. The NF- $\kappa B$ mRNA levels also increased in a time-dependent manner except the $\mathrm{L}$ group of cerebellum, which increased first and then decreased $(P<0.05)$.

\section{Effects of $\mathrm{As}_{2} \mathrm{O}_{3}$ on the iNOS mRNA levels in the brain tissues of chickens}

The mRNA levels of iNOS were displayed in Fig. 3. The iNOS mRNA levels were found to be significantly increased in a time-dependent manner after $\mathrm{As}_{2} \mathrm{O}_{3}$ treatment in the cerebrum, cerebellum, thalamus, brainstem and myelencephalon tissues compared with the control chickens $(P<0.05)$. The mRNA levels of iNOS also increased in a dose-dependent manner except for the $\mathrm{H}$
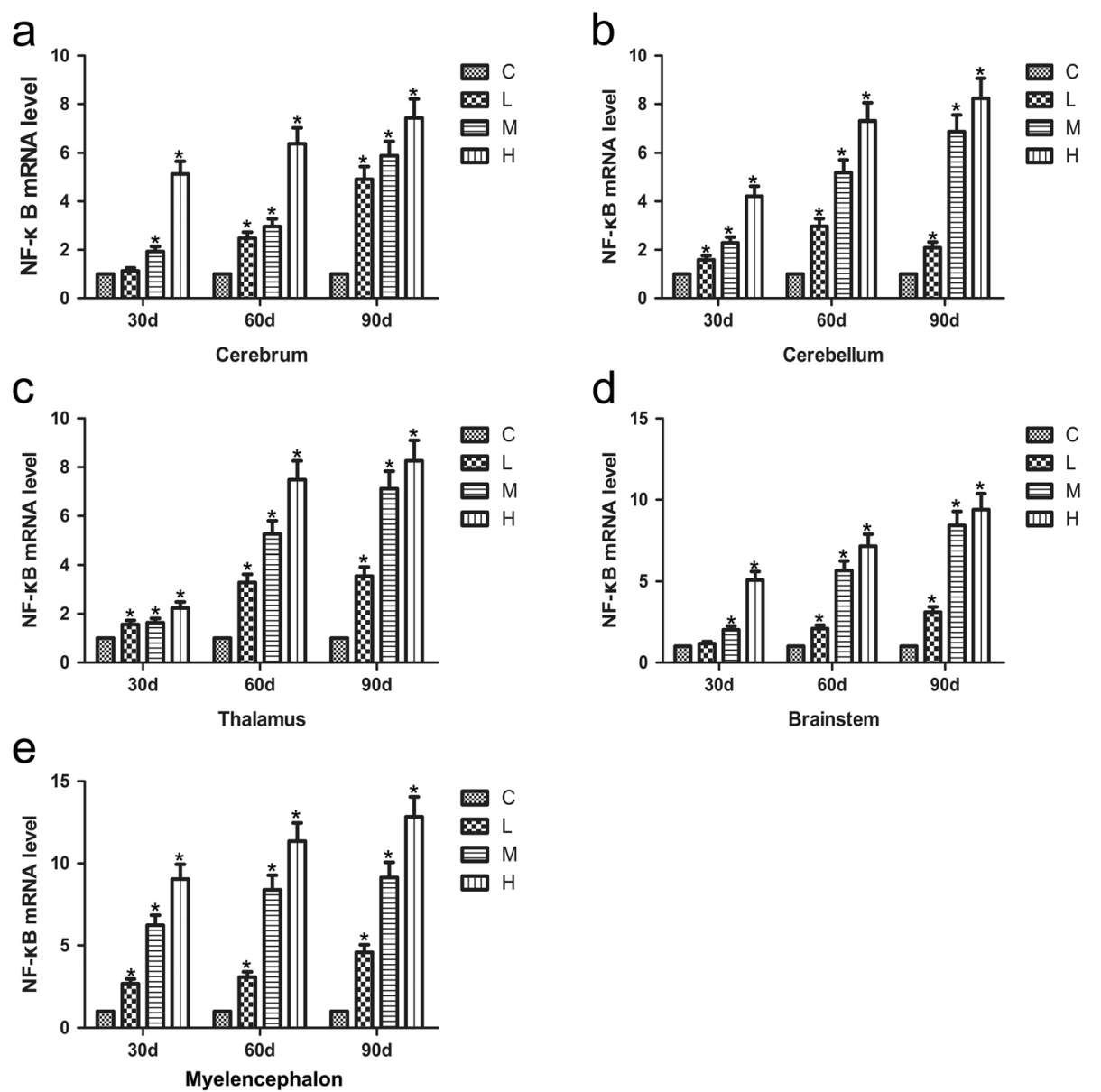

Fig. 2 Effects of $\mathrm{As}_{2} \mathrm{O}_{3}$ on the NF-kB mRNA levels in the brain tissues. a-e represented the NF-kB mRNA levels in the cerebrum, cerebellum, thalamus, brainstem and myelencephalon tissue, respectively. Each value represented the means \pm SD of six individuals. The bars with a star at the same sampling time were significantly different $(P<0.05)$ 

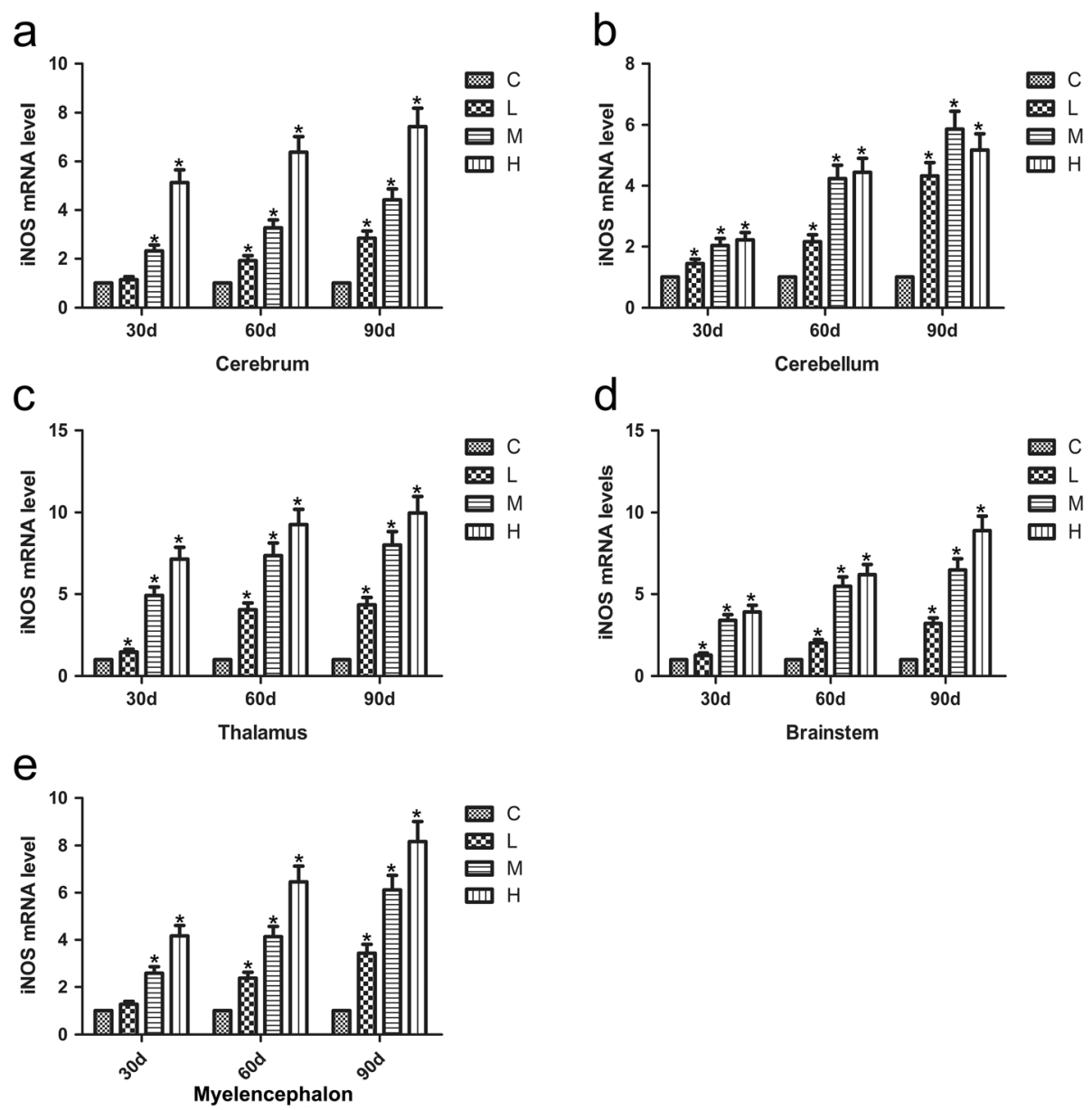

Fig. 3 Effects of $\mathrm{As}_{2} \mathrm{O}_{3}$ on the iNOS mRNA levels in the brain tissues. a-e represented the iNOS mRNA levels in the cerebrum, cerebellum, thalamus, brainstem and myelencephalon tissue, respectively. Each value represented the means \pm SD of six individuals. The bars with a star at the same sampling time were significantly different $(P<0.05)$

group in the cerebellum, which was lower than that of the corresponding $\mathrm{M}$ group at $90 \mathrm{~d}(P<0.05)$.

\section{Effects of $\mathrm{As}_{2} \mathrm{O}_{3}$ on the COX-2 mRNA levels in the brain tissues of chickens}

The COX-2 mRNA levels in the cerebellum, thalamus and brainstem tissues of chickens treated with $\mathrm{As}_{2} \mathrm{O}_{3}$ increased in a time- and dose-dependent manner compared with the controls (Fig. $4, P<0.05$ ). However, the COX-2 mRNA levels of the $\mathrm{H}$ group was lower than that of the $\mathrm{M}$ group in the cerebrum at $90 \mathrm{~d}$, whereas the COX-2 mRNA levels in the $\mathrm{L}$ and $\mathrm{M}$ groups increased in a time- and dose-dependent fashion $(P<0.05)$. The COX-2 mRNA levels of the $\mathrm{H}$ group were slightly lower than those of the corresponding $\mathrm{M}$ group in the myelencephalon tissue at $30 \mathrm{~d}$, whereas the COX-2 levels were found to be obviously increased in a dose-dependent manner at $60 \mathrm{~d}$ and $90 \mathrm{~d}(P<0.05)$.
Effects of $\mathrm{As}_{2} \mathrm{O}_{3}$ on the mRNA levels of PTGEs in chicken brain tissue

The mRNA levels of PTGEs increased in a time- and dose-dependent fashion in the cerebrum, cerebellum, and thalamus of chickens exposed to $\mathrm{As}_{2} \mathrm{O}_{3}$ compared with the controls (Fig. $5, P<0.05$ ). In the brainstem, the $\mathrm{L}$ and $\mathrm{M}$ groups showed an increasing time- and dosedependent trend $(P<0.05)$; however, at $60 \mathrm{~d}$, the $\mathrm{H}$ group had slightly increased mRNA levels of PTGEs compared with the L group $(P<0.05)$. In the myelencephalon, all groups except the $\mathrm{H}$ group showed a dosedependent increasing trend $(P<0.05)$ in the mRNA levels of PTGEs. The $\mathrm{H}$ group had lower mRNA levels of PTGEs at $90 \mathrm{~d}$ than at both the 30 and $60 \mathrm{~d}$ time points $(P<0.05)$.

\section{Western blot analysis of the iNOS levels}

$\mathrm{As}_{2} \mathrm{O}_{3}$ treatment for a period of 90 days resulted in a significant increase $(P<0.05)$ in the protein expression 

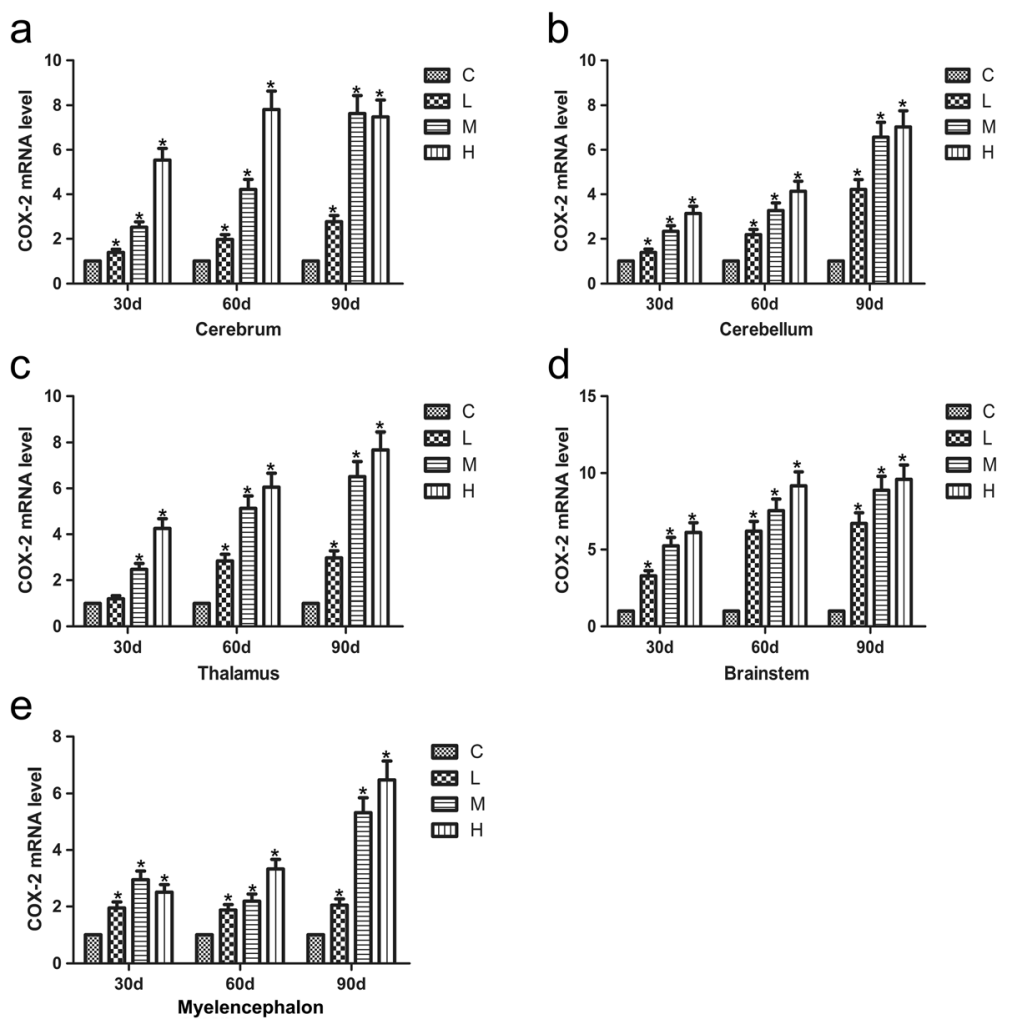

Fig. 4 Effects of $\mathrm{As}_{2} \mathrm{O}_{3}$ on the COX-2 mRNA levels in the brain tissues. a-e represented the COX-2 mRNA levels in the cerebrum, cerebellum, thalamus, brainstem and myelencephalon tissue, respectively. Each value represented the means \pm SD of six individuals. The bars with a star at the same sampling time were significantly different $(P<0.05)$

of iNOS as detected by western blot (Fig. 6). The results revealed that iNOS protein expression was significantly increased in the cerebellum, thalamus, brainstem and myelencephalon tissues in a dose-dependent manner compared with the control group $(P<0.05)$. iNOS protein levels increased at different levels in diverse tissues. Compared with the control group, the iNOS protein levels in the cerebrum tissues of the $\mathrm{As}_{2} \mathrm{O}_{3}$-treated groups increased at $30 \mathrm{~d}$, decreased at $60 \mathrm{~d}$, and slightly increased at $90 \mathrm{~d}(P<0.05)$ compared with controls.

\section{Discussion}

As a natural component of the environment, animals easily access to relatively low levels of arsenic by eating food, breathing air, and drinking water [38]. The respiratory, cardiovascular gastrointestinal, haematological, renal, dermal, reproductive, and neurological toxicity of arsenic have been recorded for centuries [2]. Therefore, it is valuable to research how environmental arsenic exposure affects organism health, particularly at low levels. One of the risk factors of neurological toxicity is arsenic. The acute or chronic exposure to inorganic arsenic causes arsenic-associated neurotoxicity in humans that cause behavioural alterations in turn $[39,40]$. In this study, we performed an ultrastructure assay of chicken brain tissues and found that arsenic trioxide exposure caused typical features of injury such as fusion of the nuclear membrane, nucleus shrinkage, chromatin condensation, and margination. The $\mathrm{As}_{2} \mathrm{O}_{3}$-induced neural injury could further trigger host defences, such as an inflammatory response. Therefore, we investigated the effect of $\mathrm{As}_{2} \mathrm{O}_{3}$ on the expression of inflammatory cytokines in the brain tissues of chickens.

When organisms are exposed to heavy metals, NF- $\mathrm{kB}$ level increases, interact with reactive oxygen species (ROS) [41] and accelerate the generation of inflammatory cytokines [42]. In our study, the expression of NF$\kappa B$ was assessed by $q R T-P C R$, and we confirmed that NF- $k B$ expression was significantly increased in a timeand dose-dependent manner except in the cerebrum and brainstem tissues from the $\mathrm{As}_{2} \mathrm{O}_{3}$-treated $\mathrm{L}$ group $(P<0.05)$. The expression of NF-kB was similar trend in a time- and dose-dependent manner in five brain tissues. Increased NF-kB activity has been found in the brain tissues of patients with Alzheimer's disease and takes part in the neurodegenerative process [43]. Our results showed that arsenic activated NF- $\mathrm{KB}$ expression in the brain tissues of chickens, which might further induce the expression of other pro-inflammatory genes such as TNF- $\alpha$, IL-6, iNOS, and COX-2 involved in the inflammatory process. 

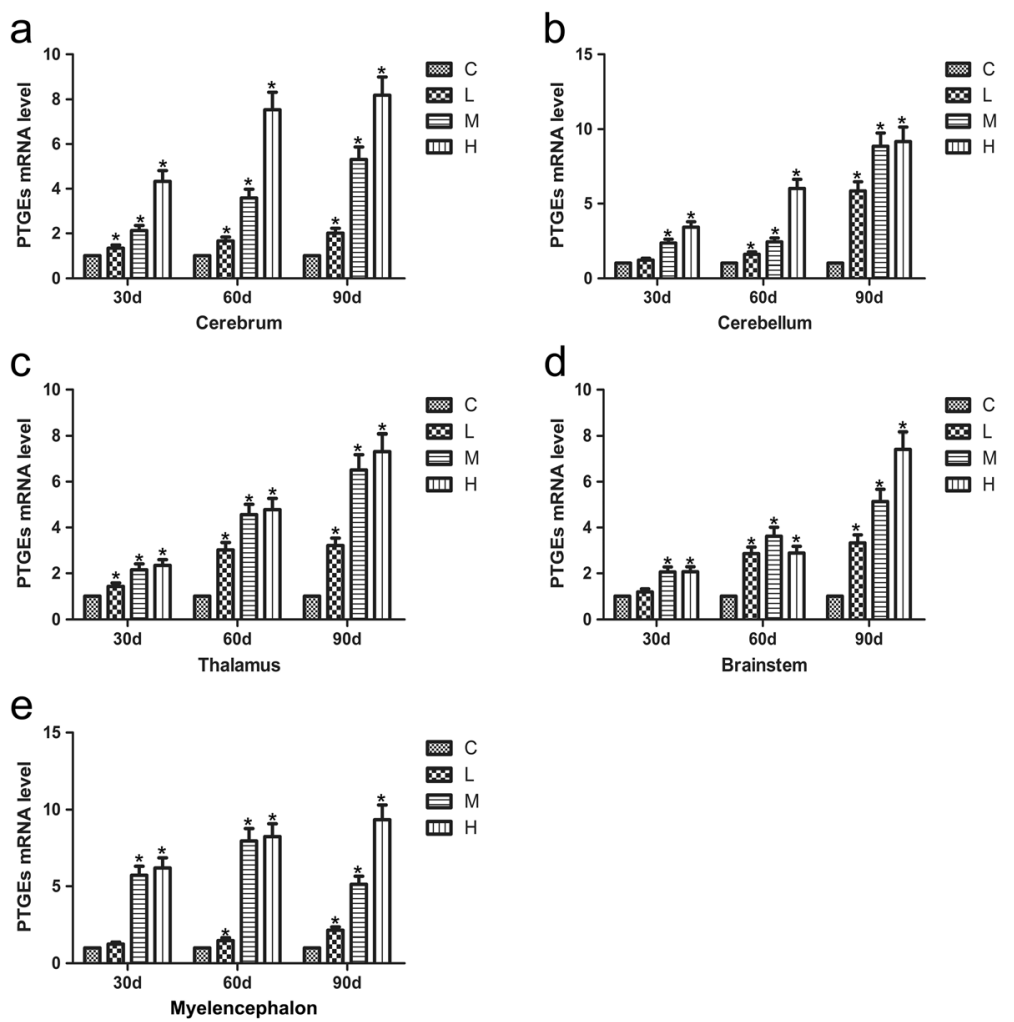

Fig. 5 Effects of $\mathrm{As}_{2} \mathrm{O}_{3}$ on the PTGEs mRNA levels in the brain tissues. a-e represented the PTGEs mRNA levels in the cerebrum, cerebellum, thalamus, brainstem and myelencephalon tissue, respectively. Each value represented the means \pm SD of six individuals. The bars with a star at the same sampling time were significantly different $(P<0.05)$

NOS expression has a wide range of distribution and has been found in endothelial cells, glial cells, neurons, and perivascular nerves $[27,28]$. iNOS is a member of the NOS family and is expressed in inflammatory cells and nerve cells including astrocytes and microglia [44-46]. Thus, iNOS is well known to be abundant in brain tissue $[47,48]$. In our study, we examined iNOS mRNA and protein levels by qRT-PCR and western blot, respectively. The iNOS mRNA levels were significantly increased in the brain tissues of the $\mathrm{As}_{2} \mathrm{O}_{3}$-treated groups except for the cerebellum tissues of the $\mathrm{H}$ group and the cerebrum tissues of the L group $(P<0.05)$, suggesting that iNOS might play a role in inducing brain tissue inflammation upon arsenic exposure. In the cerebrum, there was a fluctuation in protein expression that may have been related to post transcriptional regulation of gene expression [49]. Madrigal et al. reported that the iNOS level could be decreased in the brain cortex of animals treated with an NF- $\mathrm{KB}$ inhibitor [50]. This provides further evidence that in our study, the activation of NF- $\mathrm{kB}$ through arsenic exposure induced iNOS production in different brain tissues.

In addition, it is believed that COX-2 is of primary importance in the inflammatory response [51]. Several studies have shown that kainic acid can lead to the induction of COX-2 expression and neuronal apoptosis. Excitotoxin induces neuronal death in vitro and is accompanied by a selective elevation in the mRNA level of COX-2. Nonsteroidal anti-inflammatory drugs cause the contents of COX to vary in vivo [52]. These observations demonstrate that the expression of COX-2 may be involved in the pathway leading to neuronal death. COX-2 expression and the subsequent prostaglandin E2 (PTGE2) production are both used as prognostic markers of inflammation [53]. Additionally, these two markers are regarded as targets of therapeutic intervention during the inflammatory response. In the tissues damage, enzymes of iNOS and cyclooxygenase-2 (COX-2) could induce the generation of prostaglandin $\mathrm{E}$ synthase (PTGEs) [34]. And following the initiation of COX-2 expression, TNF- $\alpha$ could induce the activation of NF- $\kappa B$ in the COX-2 promoter [54]. Consistent with these previous studies, the mRNA levels of COX-2 and the PTGEs were up-regulated in time- and dose-dependent manners in the brain tissues from $\mathrm{As}_{2} \mathrm{O}_{3}$-treated chickens $(P<0.05)$ compared with the control group, especially myelencephalon. The results illustrated that NF- $\mathrm{kB}$ activation also up-regulated the expression of iNOS, COX-2 and the PTGEs to take part in an arsenic-induced inflammatory response in the brain tissues of chickens. 


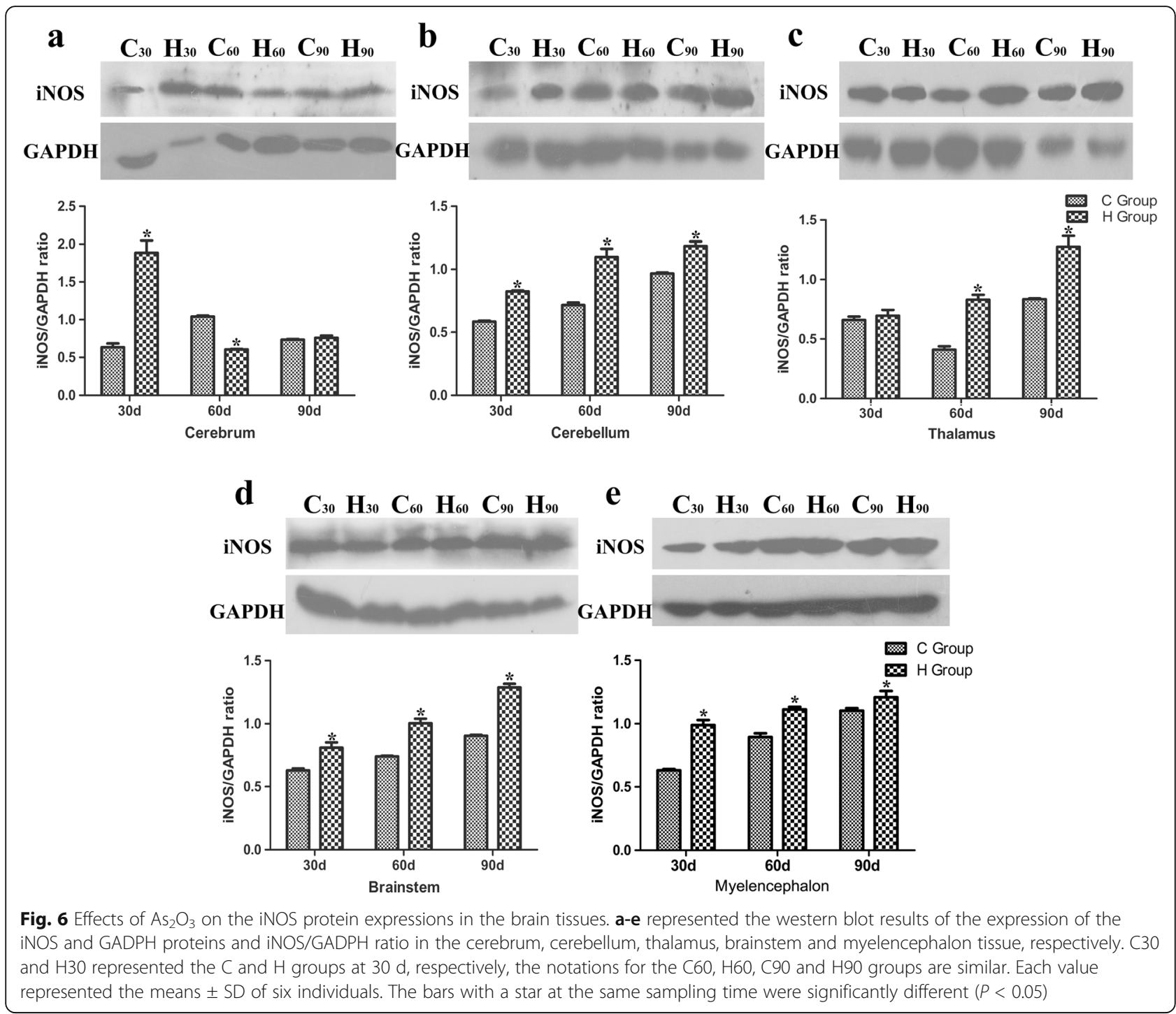

\section{Conclusion}

In conclusion, we demonstrated that arsenic exposure in chickens affected the expression of inflammatory cytokines in their brain tissues. Arsenic could trigger host defence and induce an inflammatory response in the brain tissues of chickens. The mRNA levels of NF$\kappa B, i N O S, C O X-2$ and PTGEs and the protein levels of iNOS were significantly up-regulated in the brain tissues from $\mathrm{As}_{2} \mathrm{O}_{3}$-treated chickens compared with the controls. The mechanisms of neurotoxicity induced by arsenic could lead to inflammatory response in chicken brain tissues.

\section{Additional file}

Additional file 1: Table S1. Primers used for quantitative real-time PCR. (DOC $33 \mathrm{~kb}$ )

\section{Abbreviations}

$\mathrm{As}_{2} \mathrm{O}_{3}$ : Arsenic trioxide; COX-2: Cyclooxygenase-2; iNOS: Inducible NO synthase; IKB: inhibitors of $\mathrm{kB}$; NF-kB: Nuclear transcription factor-kB; PTGE2: Prostaglandin E2; PTGEs: Prostaglandin E synthase; ROS: Reactive oxygen species

\section{Acknowledgements}

We thank American Journal Experts for critical modification of this manuscript. At the same time, we thank Dr. Xu Shiwen (College of Animal Medicine, Northeast Agricultural University, Harbin, China) for his supply for iNOS primary antibody.

\section{Funding}

This study was supported by the National Natural Science Foundation of China (Grant No. 31672619), the Fundamental Research Funds for the Central Universities (Grant No. 2572016EAJ5) and the Natural Science Foundation of Heilongjiang Province (Grant No. C2015061).

\section{Availability of data and materials}

All data pertaining to this study supporting these findings is contained within the manuscript and additional supporting files. 


\section{Authors' contributions}

XS performed the experiment and drafted the manuscript. YH contributed in experiment design and manuscript revision. YG, XS, YH carried out the statistical analysis. SL helped in conceived of the study, and participated in its design. $\mathrm{HZ}$ and YW carried the sampling and histological preparation. JZ, MW conceived the idea, designed the experiment, and revised the manuscript. All authors read and approved the final manuscript.

\section{Competing interests}

The authors declare that they have no competing interests.

\section{Consent for publication}

Not applicable.

\section{Ethics approval}

Ethics treatment of animals and procedures used in the present study were approved by the Institutional Animal Care and Use Committee of Northeast Forestry University (Harbin, China) (UT-31; 20 June 2014).

\section{Publisher's Note}

Springer Nature remains neutral with regard to jurisdictional claims in published maps and institutional affiliations.

\section{Received: 19 September 2016 Accepted: 18 May 2017 Published online: 05 June 2017}

\section{References}

1. Martinez VD, Vucic EA, Becker-Santos DD, Gil L, Lam WL. Arsenic exposure and the induction of human cancers. J Toxicol. 2011;2011:431287.

2. Mandal BK, Suzuki KT. Arsenic round the world: a review. Talanta. 2002;58(1): 201-35

3. Suzuki T, Yamashita S, Ushijima T, Takumi S, Sano T, Michikawa T, et al. Genome-wide analysis of DNA methylation changes induced by gestational arsenic exposure in liver tumors. Cancer Sci. 2013:104(12):1575-85.

4. Hunt KM, Srivastava RK, Elmets CA, Athar M. The mechanistic basis of arsenicosis: pathogenesis of skin cancer. Cancer Lett. 2014:354(2):211-9.

5. Milton AH, Hasan Z, Rahman A. Chronic arsenic poisoning and respiratory effects in Bangladesh. J Occup Health. 2001:43:136-40.

6. Mazumder DN, Haque R, Ghosh N, De BK, Santra A, Chakraborti D, et al. Arsenic in drinking water and the prevalence of respiratory effects in West Bengal, India. Int J Epidemiol. 2000;29(6):1047-52.

7. Zhang K, Zhao P, Guo G, Guo Y, Tian L, Sun X, et al. Arsenic trioxide attenuates NF-kappaB and cytokine mRNA levels in the livers of cocks. Biol Trace Elem Res. 2016;170(2):432-7.

8. Giberson A, Vaziri ND, Mirahamadi K, Rosen SM. Hemodialysis of acute arsenic intoxication with transient renal failure. Arch Intern Med. 1976; 136(11):1303-4.

9. Nordstrom S, Beckman L, Nordenson I. Occupational and environmental risks in and around a smelter in northern Sweden. V. Spontaneous abortion among female employees and decreased birth weight in their offspring. Hereditas. 1979:90(2):291-6.

10. Hopenhayn-Rich C, Biggs ML, Fuchs A, Bergoglio R, Tello EE, Nicolli H, et al. Bladder cancer mortality associated with arsenic in drinking water in Argentina. Epidemiology. 1996;7(2):117-24

11. Yao HD, Wu Q, Zhang ZW, Zhang JL, Li S, Huang JQ, et al. Gene expression of endoplasmic reticulum resident selenoproteins correlates with apoptosis in various muscles of se-deficient chicks. J Nutr. 2013;143(5):613-9.

12. Yao HD, Wu Q, Zhang ZW, Li S, Wang XL, Lei XG, et al. Selenoprotein W serves as an antioxidant in chicken myoblasts. Biochim Biophys Acta. 2013; 1830(4):3112-20.

13. Nagaraja TN, Desiraju T. Effects on operant learning and brain acetylcholine esterase activity in rats following chronic inorganic arsenic intake. Hum Exp Toxicol. 1994:13(5):353-6.

14. Rodriguez VM, Jimenez-Capdeville ME, Giordano M. The effects of arsenic exposure on the nervous system. Toxicol Lett. 2003:145(1):1-18.

15. Han FX, Kingery WL, Selim HM, Gerard PD, Cox MS, Oldham JL. Arsenic solubility and distribution in poultry waste and long-term amended soil. Sci Total Environ. 2004;320(1):51-61.

16. Cao H, Gao F, Xia B, Zhang M, Liao Y, Yang Z, et al. Alterations in trace element levels and mRNA expression of Hsps and inflammatory cytokines in livers of duck exposed to molybdenum or/and cadmium. Ecotoxicol Environ Saf. 2016;125:93-101.

17. Sun GX, Chen Y, Liu CP, Li S, Fu J. Effect of selenium against lead-induced damage on the gene expression of heat shock proteins and inflammatory cytokines in peripheral blood lymphocytes of chickens. Biol Trace Elem Res. 2016;172(2):474-80.

18. Sheng PF, Jiang Y, Zhang ZW, Zhang JL, Li S, Zhang ZQ, et al. The effect of se-deficient diet on gene expression of inflammatory cytokines in chicken brain. Biometals. 2014;27(1):33-43.

19. Rice D, Barone SJ. Critical periods of vulnerability for the developing nervous system: evidence from humans and animal models. Environ Health Perspect. 2000;108(Suppl 3):511-33.

20. Lalwani S, Dogra TD, Bhardwaj DN, Sharma RK, Murty OP, Vij A. Study on arsenic level in ground water of Delhi using hydride generator accessory coupled with atomic absorption spectrophotometer. Indian J Clin Biochem. 2004:19(2):135-40.

21. Wang CX, Shuaib A. Involvement of inflammatory cytokines in central nervous system injury. Prog Neurobiol. 2002;67(2):161-72.

22. Chen CJ, Ou YC, Lin SY, Liao SL, Chen SY, Chen JH. Manganese modulates pro-inflammatory gene expression in activated glia. Neurochem Int. 2006; 49(1):62-71.

23. Makarov SS. NF-kappaB as a therapeutic target in chronic inflammation: recent advances. Mol Med Today. 2000;6(11):441-8.

24. Lawrence T, Gilroy DW, Colville-Nash PR, Willoughby DA. Possible new role for NF-kappaB in the resolution of inflammation. Nat Med. 2001;7(12):1291-7.

25. Tak PP, Firestein GS. NF-kappaB: a key role in inflammatory diseases. J Clin Invest. 2001;107(1):7-11.

26. Chen LJ, Sun BH, Qu JP, Xu S, Li S. Avermectin induced inflammation damage in king pigeon brain. Chemosphere. 2013;93(10):2528-34.

27. Bredt DS, Snyder SH. Isolation of nitric oxide synthetase, a calmodulinrequiring enzyme. Proc Natl Acad Sci U S A. 1990;87(2):682-5.

28. Murphy S, Simmons ML, Agullo L, Garcia A, Feinstein DL, Galea E, et al. Synthesis of nitric oxide in CNS glial cells. Trends Neurosci. 1993;16(8):323-8.

29. Pasinetti GM. Cyclooxygenase and inflammation in Alzheimer's disease: experimental approaches and clinical interventions. J Neurosci Res. 1998;54(1):1-6.

30. Yenari MA, Han HS. Neuroprotective mechanisms of hypothermia in brain ischaemia. Nat Rev Neurosci. 2012;13(4):267-78.

31. Mattson MP, Camandola S. NF-kappaB in neuronal plasticity and neurodegenerative disorders. J Clin Invest. 2001:107(3):247-54.

32. Liu RH, Hotchkiss JH. Potential genotoxicity of chronically elevated nitric oxide: a review. Mutat Res. 1995:339(2):73-89.

33. Tunctan B, Uludag O, Altug S, Abacioglu N. Effects of nitric oxide synthase inhibition in lipopolysaccharide-induced sepsis in mice. Pharmacol Res. 1998;38(5):405-11.

34. Surh YJ, Chun KS, Cha HH, Han SS, Keum YS, Park KK, et al. Molecular mechanisms underlying chemopreventive activities of anti-inflammatory phytochemicals: down-regulation of COX-2 and iNOS through suppression of NF-kappa B activation. Mutat Res. 2001:480-481:243-68.

35. Xing M, Zhao P, Guo G, Guo Y, Zhang K, Tian L, et al. Inflammatory factor alterations in the gastrointestinal tract of cocks overexposed to arsenic trioxide. Biol Trace Elem Res. 2015;167(2):288-99.

36. Nisianakis P, Giannenas I, Gavriil A, Kontopidis G, Kyriazakis I. Variation in trace element contents among chicken, turkey, duck, goose, and pigeon eggs analyzed by inductively coupled plasma mass spectrometry (ICP-MS). Biol Trace Elem Res. 2009;128(1):62-71.

37. Zhao FQ, Zhang ZW, Wang C, Zhang B, Yao HD, Li S, et al. The role of heat shock proteins in inflammatory injury induced by cold stress in chicken hearts. Cell Stress Chaperones. 2013:18(6):773-83.

38. Hughes MF, Beck BD, Chen Y, Lewis AS, Thomas DJ. Arsenic exposure and toxicology: a historical perspective. Toxicol Sci. 2011;123(2):305-32.

39. Tsuji JS, Garry MR, Perez V, Chang ET. Low-level arsenic exposure and developmental neurotoxicity in children: a systematic review and risk assessment. Toxicology. 2015;337:91-107.

40. Vahidnia A, Romijn F, Tiller M, van der Voet GB, de Wolff FA. Arsenicinduced toxicity: effect on protein composition in sciatic nerve. Hum Exp ToxicoL. 2006;25(11):667-74.

41. Liu X, Nie S, Huang D, Xie M. Nonylphenol regulates cyclooxygenase-2 expression via Ros-activated NF-kappaB pathway in sertoli TM4 cells. Environ Toxicol. 2015:30(10):1144-52.

42. Read MA, Whitley MZ, Williams AJ, Collins T. NF-kappa B and I kappa B alpha: an inducible regulatory system in endothelial activation. J Exp Med. 1994;179(2):503-12. 
43. Kaltschmidt B, Widera D, Kaltschmidt C. Signaling via NF-kappaB in the nervous system. Biochim Biophys Acta. 2005;1745(3):287-99.

44. Marletta MA. Nitric oxide synthase: aspects concerning structure and catalysis. Cell. 1994:78(6):927-30.

45. Nathan C, Xie QW. Nitric oxide synthases: roles, tolls, and controls. Cell. 1994;78(6):915-8.

46. Di Monte DA, Royland JE, Anderson A, Castagnoli K, Castagnoli NJ, Langston JW. Inhibition of monoamine oxidase contributes to the protective effect of 7-nitroindazole against MPTP neurotoxicity. J Neurochem. 1997;69(4):1771-3.

47. Araki T, Tanji H, Fujihara K, Kato H, Itoyama Y. Increases in [3H]FK-506 and [3H]L-N(G)-nitro-arginine binding in the rat brain after nigrostriatal dopaminergic denervation. Metab Brain Dis. 1999;14(1):21-31.

48. Muramatsu Y, Kurosaki R, Watanabe H, Michimata M, Matsubara M, Imai Y, et al. Cerebral alterations in a MPTP-mouse model of Parkinson's disease-an immunocytochemical study. J Neural Transm (Vienna). 2003:1 10(10):1129-44.

49. Casper I, Nowag S, Koch K, Hubrich T, Bollmann F, Henke J, et al. Posttranscriptional regulation of the human inducible nitric oxide synthase (iNOS) expression by the cytosolic poly(A)-binding protein (PABP). Nitric Oxide. 2013;33:6-17.

50. Madrigal JL, Moro MA, Lizasoain I, Lorenzo P, Castrillo A, Bosca L, et al. Inducible nitric oxide synthase expression in brain cortex after acute restraint stress is regulated by nuclear factor kappaB-mediated mechanisms. J Neurochem. 2001;76(2):532-8.

51. O'Banion MK. COX-2 and Alzheimer's disease: potential roles in inflammation and neurodegeneration. Expert Opin Investig Drugs. 1999; 8(10):1521-36.

52. Hirsch EC, Breidert T, Rousselet E, Hunot S, Hartmann A, Michel PP. The role of glial reaction and inflammation in Parkinson's disease. Ann N Y Acad Sci. 2003;991:214-28.

53. Zhang W, Zhang R, Wang $T$, Jiang $H$, Guo M, Zhou E, et al. Selenium inhibits LPS-induced pro-inflammatory gene expression by modulating MAPK and NF-kappaB signaling pathways in mouse mammary epithelial cells in primary culture. Inflammation. 2014;37(2):478-85.

54. Chen CC, Sun YT, Chen JJ, Chiu KT. TNF-alpha-induced cyclooxygenase-2 expression in human lung epithelial cells: involvement of the phospholipase C-gamma 2, protein kinase C-alpha, tyrosine kinase, NF-kappa B-inducing kinase, and I-kappa B kinase 1/2 pathway. J Immunol. 2000;165(5):2719-28.

\section{Submit your next manuscript to BioMed Central and we will help you at every step:}

- We accept pre-submission inquiries

- Our selector tool helps you to find the most relevant journal

- We provide round the clock customer support

- Convenient online submission

- Thorough peer review

- Inclusion in PubMed and all major indexing services

- Maximum visibility for your research

Submit your manuscript at www.biomedcentral.com/submit 